\title{
Percentage Analysis Mixed of CPO, Phosphic Acid and Sodium Hydroxide as a Replacement for Diesel Engine Oil Fuel Using a Calorize Test
}

\author{
${ }^{1}$ Yuspian Gunawan ${ }^{*},{ }^{2}$ La Hasanuddin, ${ }^{3}$ Raden Rinova Sisworo, ${ }^{4}$ Agustinus Lolok, ${ }^{5}$ Bunyamin, \\ ${ }^{6}$ Nanang Endriatno, ${ }^{7}$ Muhlas Adi Putra \\ ${ }_{1,2,3,6}$ Mechanical Engineering, Halu Oleo University-Indonesia \\ ${ }^{4,5}$ Electrical Engineering Alumni, Halu Oleo University-Indonesia \\ ${ }^{7}$ Mechanical Engineering Alumni, Halu Oleo University-Indonesia
}

\begin{abstract}
One of the researches being developed is to produce methyl esters from CPO through transesterification reaction of vegetable oil (triglycerides) with methanol. Biodiesel from crude palm oil is a new hope for answering some of the energy needs. know the rate of combustion of the biodiesel produced. Biodiesel that is produced from a mixture of CPO, phosphoric acid and sodium hydroxide, with a percentage of I. 98\% CPO, 1\% Phosphoric Acid, 1\% Sodium Hydroxide: II. 95\% CPO, 2\% Phosphoric Acid, 3\% Sodium Hydroxide: III. 95\% CPO, 3\% Phosphoric Acid, 2\% Sodium Hydroxide. The results showed that the most effective mixture was $95 \%$ CPO, $3 \%$ acid phosphate and $2 \%$ sodium hydroxide with a burning rate of 0.309 $\mathrm{g} /$ minute in 30.42 minutes with a final temperature of 57 (oC).
\end{abstract}

Keywords: CPO, Phosphoric Acid, Sodium Hydroxide, Biodiesel, Energy, Heat Value, Combustion Rate.

\section{Background}

Energy demand continues to increase in line with industrial development and world population growth. The increasing need for fuel oil causes the supply of crude oil to decrease. This causes an impact on the energy crisis that occurs in the world, especially from fossil fuels, resulting in an increase in the price of fuel oil (BBM). One of the potential alternatives to be developed in response to the energy crisis is the use of biodiesel which is produced from biological raw materials. Biodiesel is a renewable alternative fuel produced from vegetable oil, one of which is palm oil which is commonly known as Crude Palm Oil (CPO). So far, palm oil has been widely used for cooking oil. For this reason, a research effort is needed to be able to find ways to utilize palm oil into a product that can provide more benefits for human life. [1]

The energy crisis has caused the price of crude oil to become expensive so that environmental concerns have prompted the government and society to establish a national energy policy with an emphasis on renewable energy such as biodiesel to reduce fossil fuel consumption and to improve the country's energy security. [2]

Indonesia is claimed to be the largest producer of palm oil or CPO (Crude Palm Oil) in the world and has a vision of realizing Indonesia using new renewable energy sources (substitute for fossil) as much as $25 \%$ by 2025 in the framework of energy conservation and energy diversification. [1]

A material can be used as a raw material for biodiesel with the following conditions that the material has a triglyceride composition above $95 \%$ and contains FFA (Free Fatty Acid) or free fatty acids below $2 \%$. If an oil sample contains FFA above $2 \%$, a pre-treatment process must be carried out first, namely the esterification reaction from FFA to methyl ester. [3]

\section{Formulation of the problem}

The formulation of the problem from this research is as follows:

1. What is the heating value of the biodiesel produced?

2. What is the rate of combustion of the biodiesel produced? 


\section{Research purposes}

The research objectives of this study are as follows:

1. To determine the heating value of the biodiesel produced

2. To determine the rate of combustion of the biodiesel produced

\section{Basic Theory}

\section{Energy and Renewable Energy}

Energy is something abstract that is difficult to prove but can be felt. Energy is the ability to do work (energy is the capacity for doing work). Based on the source, energy can be divided into energy that comes from the earth (terrestrial) and that comes from outside the earth (extraterrestrial), based on its nature. Energy sources can also be classified. Energy sources from the earth are categorized as renewable or non-depleted and nonrenewable) or depleted energy. Renewable or recyclable energy sources, for example wood energy, biomass, biogas. Energy sources that come from outside the earth, such as solar energy and cosmic ray energy, which are non-depleted energy resources. Meanwhile, energy sources such as oil, coal and natural gas are non-renewable or consumable energy sources. [4]

There are many major sources of energy and they are classified into two broad groups as follows:

1. Conventional energy is energy taken from sources that are only available in limited quantities on earth and cannot be regenerated. These energy sources will end up sooner or later and are dangerous for the environment.

2. Renewable energy is energy that is generated from natural sources such as sun, wind and water and can be generated again and again. Resources will always be available and will not harm the environment. Conventional and Renewable energy sources can be converted into secondary energy sources, such as electricity. Electricity is different from other energy sources and is called a secondary energy source or energy carrier because it is used to store, move or distribute energy conveniently. Primary energy sources are needed to produce electrical energy. [5]

Renewable energy sources are energy sources that are continuously and freely produced in nature and cannot be used up. For example: solar energy, biomass and wood energy, geo-thermal energy, wind energy, tidal energy and ocean energy. Renewable energy sources derive their energy from existing energy flows from ongoing natural processes, such as sunlight, wind, water flows, biological processes, and geothermal flows. The general definition of renewable energy sources is that renewable energy is taken from energy sources which are quickly replaced by natural processes such as power generated from the sun or wind. Currently, the most promising (aka most economical) alternative energy sources include wind power, solar power, and hydropower. Other renewable sources include geothermal and marine energy, as well as biomass and ethanol as renewable fuels. [6]

Over the past quarter century, the twin concepts of sustainability and renewable energy have emerged as defining imperatives of humanity that lie at the nexus of science, technology, culture, economy, policy and the environment. This twin concept is framed as a means of reducing the negative impacts of depletion of natural resources, energy consumption, water consumption and greenhouse gas emissions that alter the climate of associated anthropogenic activities. Due to the problems of the energy, environmental, economic, political, market and social crises, researchers are interested in developing sustainable and renewable energy sources to secure energy consumption, protect the environment, and promote regional development. [7]

$\mathrm{CO} 2, \mathrm{CFCs}$ and other hazardous gases are produced through the use of available natural sources. The air is polluted through these gases, so renewable energy would be the best solution. Developed countries are looking for new alternative energy sources to minimize pressure on natural sources such as gas, oil, coal etc. [8]

\section{Fuel}

Fuel is needed for the engine to produce work. Types of reciprocating internal combustion engines are classified according to the mode of ignition, these fuels: for example, spark ignition (SI) or compression ignition (CI). The specific effect of changing certain fuel properties depends on many detailed engine parameters and the combustion strategy in which the fuel is used, as well as the conditions in which the engine is operated. SI engines typically perform better with high volatility fuel resistant to auto start (gasoline), while CI engines tend to perform better with fuels exhibiting opposing volatility and flame characteristics (diesel fuel). The chemical 
composition of the fuel determines its properties, and the properties of the fuel determine the performance characteristics of the engine. Historically, liquid phase hydrocarbon fuels used for transportation and off-road applications have been refined from crude oil extracted from below the earth's surface. Hydrocarbons are compounds that only contain the elements hydrogen and carbon. A compound is defined as a pure chemical consisting of two or more elements that are bonded in a certain structural arrangement and show a fixed ratio of different elements. The word "petroleum" comes from Latin roots; the literal translation is "rock oil". [9]

\section{Combustion}

Combustion (Latin: combustio, burning) is an exothermic chemical reaction, specifically the oxidation of fuels, which liberates energy that can be used for various purposes. In the reaction, the fast, the radicals are involved. Combustion is a ubiquitous technology. It is used in power generation, land, sea and air transportation, spacecraft propulsion, heating, materials processing and other technologies. It occurs in industrial furnaces and boilers, foundries, kilns, ovens, incinerators, machinery and household stoves, in mobile and stationary applications. The phenomenon of burning " fire " releases heat, light, and various reaction products in a selfcontained oxidation reaction. The part of the flame that is visible in the gas phase, the reaction zone, is called the flame. The chemiluminescence and incandescence of the shining soot particles give the flame its distinctive color. [10]

\section{Used Cooking Oil}

Used cooking oil is waste and when viewed from its chemical composition, used cooking oil contains carcinogenic compounds, which occur during the frying process. The sustainable use of used cooking oil can damage human health, cause cancer, and consequently reduce the intelligence of the next generation. For this reason, proper handling is needed so that used cooking oil waste can be beneficial and does not cause harm from aspects of human health and the environment. [11]

The use of used cooking oil as a raw material for making biodiesel provides several benefits, such as reducing environmental pollution in the water chart. Because people today tend to throw used cooking oil of a very low quality. In addition, the used cooking oil raw material is no longer categorized as a food ingredient considering its black and watery shape. Making biodiesel with alkaline transesterification can be done at low cost by using technical $\mathrm{NaOH}$ which is widely sold in the market and technical ethanol. [12]

Enzymatic methods that involve enzymes, especially lipase, in the alcoholysis process with used cooking oil are proven to be efficient in overcoming this problem. The potential of used cooking oil for this purpose, among others, meets the requirements as waste which makes sense considering that there is no definition of concrete waste that limits only waste. This review specifically focuses on how biodiesel fuel is produced by lipase catalysis from used cooking oil, the concept and definition of waste, and how waste oil can be a viable source. [13]

\section{Biodiesel}

The main raw material for making biodiesel is all vegetable oil which is a renewable energy source. There have been many studies on biodiesel from cooking oil. Cooking oil has been proven to be used as a raw material for making biodiesel. [14]

Biodiesel is an oxygenated bio-derivative product consisting of fatty acid methyl esters (FAMEs). 12 Esters have the general structure $\mathrm{R}-(\mathrm{C}=\mathrm{O}) \mathrm{O}-\mathrm{R}$ ', where $\mathrm{R}$ and $\mathrm{R}^{\prime}$ denote the hydrocarbon chains. [15]

Table 1: Comparison of the physical and chemical properties of biodiesel from used cooking oil. [16]

\begin{tabular}{|c|c|c|}
\hline Physical / chemical properties & Biodiesel & Solar \\
\hline densitv (40 oC). $\mathrm{kg} / \mathrm{L}$ & 850 & 820 \\
\hline Kinematic viscosity $\left(\begin{array}{ll}40 & 0 \\
\end{array}\right)$. & 3,2 & 2,0 \\
\hline Acid number, mg KOH/g & 0,5 & 0,3 \\
\hline Water content, \% vol & 0,02 & 0,05 \\
\hline flash point. ${ }^{\circ} \mathrm{C}$ & 176 & 55 \\
\hline pour point, ${ }^{\circ} \mathrm{C}$ & 9 & 18 \\
\hline Fog point. ${ }^{\circ} \mathrm{C}$ & 14,6 & - \\
\hline cetana index & 51 & - \\
\hline
\end{tabular}

Source: Paramita dkk, 2017

\section{Chemical reaction}

In the process of forming biodiesel fuel, it uses two stages, namely esterification (reducing Free Fatty Acid) and trans esterification (forming biodiesel using alcohol and a catalyst). Esterification is a process that is needed in the formation of biodiesel. The goal is to reduce free 
fatty acids (FFA), because of the presence of FFA, the formation of biodiesel is imperfect and turns into soap formation. Biodiesel can be formed if the FFA is below 2\%. [17]

\section{CPO (Crude Palm Oil)}

Crude Palm Oil is crude palm oil obtained from the extraction or from the pressing process of oil palm fruit flesh and has not undergone refining. Palm oil is usually used for foodstuffs, the cosmetic industry, the chemical industry and the animal feed industry. World palm oil production is dominated by Indonesia and Malaysia. In total, these two countries produce about $85-90 \%$ of the world's total palm oil production. [18]

Palm oil is the most consumed in the world besides soybean oil, canola oil and sunflower seed oil. One of the largest producers of palm oil in the world is Indonesia while the largest consumer is India. [19]

\section{Phosphoric Acid}

Phosphoric acid (PA) is an important industrial chemical used as an intermediate in the fertilizer industry, for metal surface treatment in the metallurgy industry and as an additive in the food industry. The PA industry is spread all over the world in Europe, Asia and America, including countries that operate rock phosphate (PR) mines and produce PA, phosphate fertilizers and phosphate-based products. [20]

Phosphoric acid (also known as orthophosphoric acid or phosphoric (V) acid is a mineral (inorganic) acid having the chemical formula H3PO4. The most common source of phosphoric acid is $85 \%$ aqueous solution; it is colorless, odorless, and non- The $85 \%$ solution is a syruplike liquid, but it is still pourable. Although phosphoric acid does not meet the strict definition of a strong acid, the $85 \%$ solution is acidic enough to be corrosive. Due to the high percentage of phosphoric acid in this reagent, at least some of it is acidic. orthophosphate condensed into polyphosphoric acid Uses of Phosphoric Acid (H3PO4), uses of phosphoric acid: [21]

1. Phosphoric acid is used as a rust remover or chemical rust remover on metal surfaces.

2. Phosphoric acid is also used as an electrolyte solution in the phosphoric acid fuel cell.
3. In the world of beauty, phosphoric acid is used as a regulator of the acidity level or $\mathrm{pH}$ for cosmetic products and other skin care.

4. In the process of producing activated carbon, phosphoric acid is used as an oxidizing chemical.

5. $90 \%$ of the world's total consumption of phosphoric acid is used for the manufacture of triple superphosphate (TSP), dominium hydrogen phosphate (DAP) and monoammonium dihydrogenphosphate (MAP) fertilizers.

6. Phosphoric acid is also used in the medical field, namely for dental care. Mixed with zinc powder, phosphoric acid is used to make zinc phosphate. Zinc phosphate itself is used as temporary dental cement.

7. For those of you who have a hobby of planting on hydroponic media, it turns out that phosphoric acid is also used to adjust the $\mathrm{pH}$ of the hydroponic solution.

\section{Properties of Fuel Oil. [22]}

Density: The ratio of the mass of the fuel to its volume at $25 \mathrm{oC}, \mathrm{kg} \mathrm{/} \mathrm{m} 3$, is useful for determining the quantity and quality of fuel.

Specific gravity: The ratio of the weight of the volume of oil to the weight of the same volume of water at a certain temperature, the density of water is 1 , measured using a hydrometer.

Viscosity: Measures the internal resistance of a fuel to flow, The most important characteristic for storage and use, Decreases with increasing temperature.

Flash point: The lowest temperature at which a fuel can be heated so that the vapor flashes when an open flame passes through it, or, the lowest temperature at which it can evaporate to form a flammable mixture in air.

Pour point: The lowest temperature at which fuel will flow, an indication of the temperature at which the fuel can be pumped.

Specific heat: $\mathrm{kCal}$ is needed to raise the temperature of $1 \mathrm{~kg}$ of oil by $1 \mathrm{oC}(\mathrm{kcal} / \mathrm{kgoC})$, indicating how much steam / electricity is needed to heat the oil to the desired temperature. 
Calorific value: Heat or energy produced per $\mathrm{Kg}$ of Fuel, Gross calorific value (GCV): fully condensed water vapor, Net calorific value (NCV): not completely condensed water vapor.

Sulfur content: Depends on crude oil source and less on refining process, Furnace oil: 2-4\% sulfur, Sulfuric acid causes corrosion

Ash content: Inorganic material in fuel, Typically $0.03-0.07 \%$, Burner tip corrosion and material / equipment breakdown at high temperatures.

Carbon residue: Tendency of oil to deposit carbonaceous solid residue on hot surfaces, Residual oil: carbon residue $>1 \%$.

Water content: Usually the supply of oil for the furnace is low ( $<1 \%$ in refineries), free form or emulsified, can damage the furnace surface and impact the fire.

Relative Costs: While there are clear price differences for residual oil, the capital investment in storage, handling and combustion systems for residual fuel oil is significantly higher than that required for refined oil.

Storage of fuel: Store in cylindrical tank above or below ground, Recommended storage: $>10$ days normal consumption, Cleaning periodically

\section{Palm oil}

Palm oil is the world's largest provider of oils and fats and also the most efficient in terms of land use among competing oil crops. Palm oil is ten times more productive than the next major vegetable oil on the market. Compared to other vegetable oils, palm oil production is arguably more environmentally friendly for at least two reasons. First, oil palm occupies the smallest area of world oilseed production. Second, one hectare planted with oil palm produces an average of about four tonnes of oil per year. In contrast, to produce that much oil from soybeans, sunflower and rapeseed, up to ten times as much land was needed. [23]

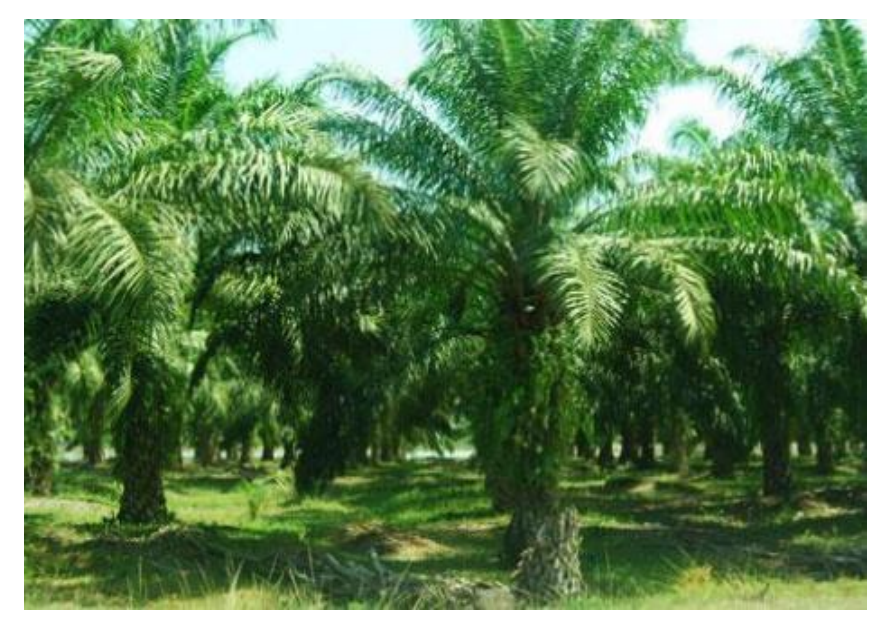

Figure 2: Oil palm plantations

\section{Source: Hamburg (2013)}

Its high resistance to oxidation and with its stress ability to dissolve chemicals that are not soluble by other solvents, as well as its high coating power make it usable for a variety of uses. The area of distribution of oil palm in Indonesia, especially in the eastern coast of Sumatra, Aceh, Kalimantan, Sulawesi and West Papua. The appearance of an oil palm tree is somewhat similar to that of a barking plant, only with spines that are not too hard and sharp. The stems of the plant are covered with fronds until they are 12 years old. After the age of 12 years, the dried fronds will come off so that the appearance is similar to coconut. This plant can reach 24 meters high. Oil is produced by fruit. The oil content increases according to the ripeness of the fruit. After passing through the mature phase, the content of free fatty acids (FFA, free fatty acids) will increase and the fruit will fall out on its own. [24]

\section{Research Methodology}

Time and Place of Research

The research was conducted in 2019 at the energy conversion laboratory, Faculty of Engineering, Halu Oleo University Kendari - Indonesia

\section{Tools and Materials}

The tools and materials used in this study are as follows:

\section{Tools}

a. Measuring cup, serves as a tool for measuring the volume of liquid 


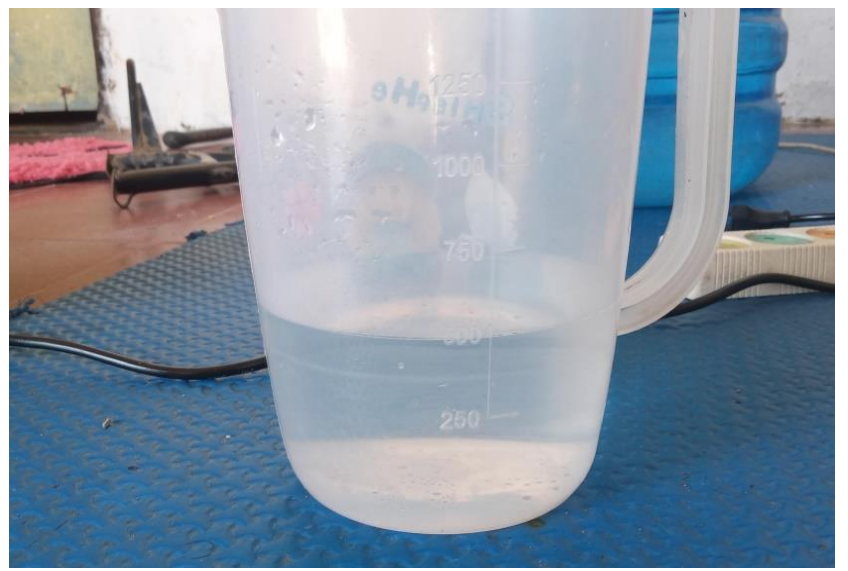

Figure 3.1 Measuring cup

b. Thermometer, serves to measure temperature

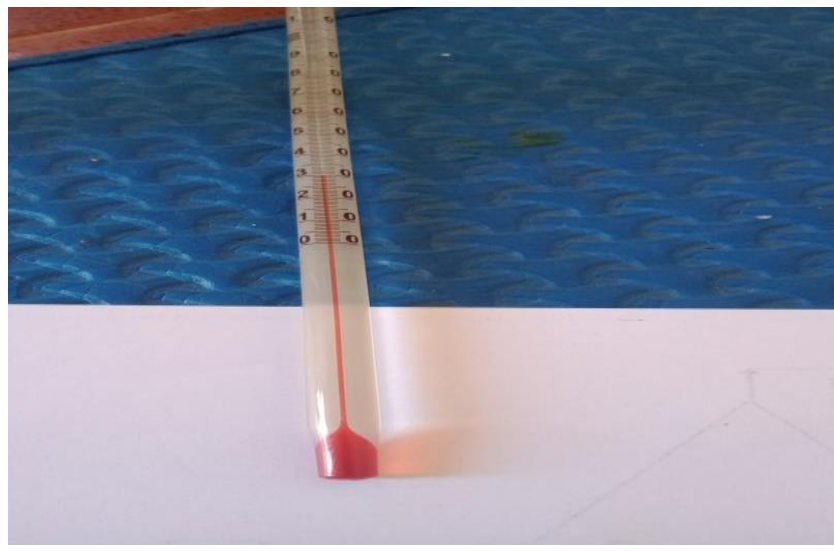

Figure 3.2 Thermometer

c. Heating pot, serves as a heating device.

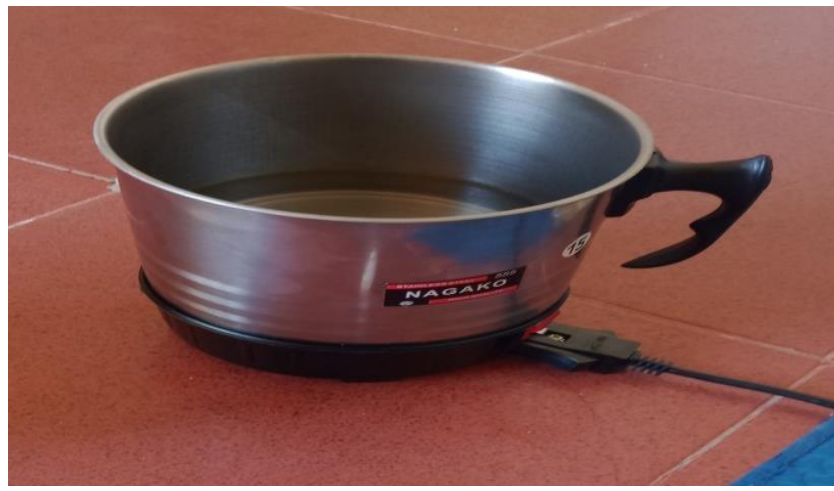

Figure 3.3 Heating pot

d. Funnel, serves as a tool to enter liquid into the

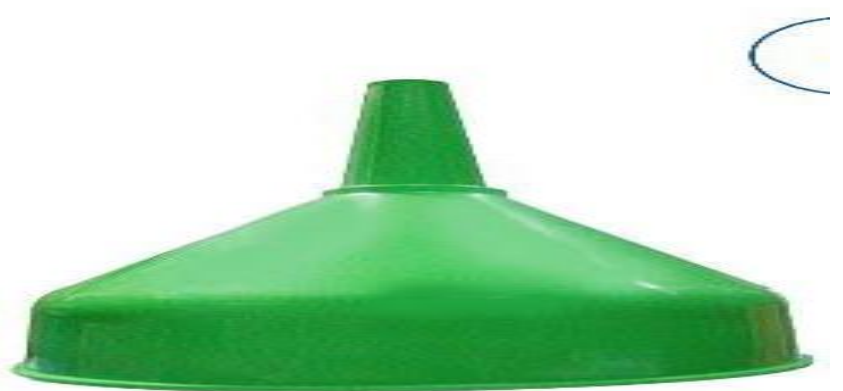

e. Bottle, serves as a container for liquid

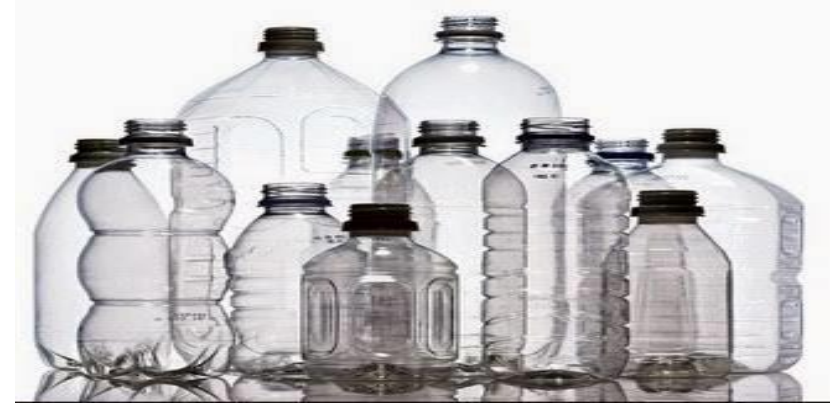

Figure 3.6 Bottles

f. Filter, is a tool for separating impurities in the CPO.

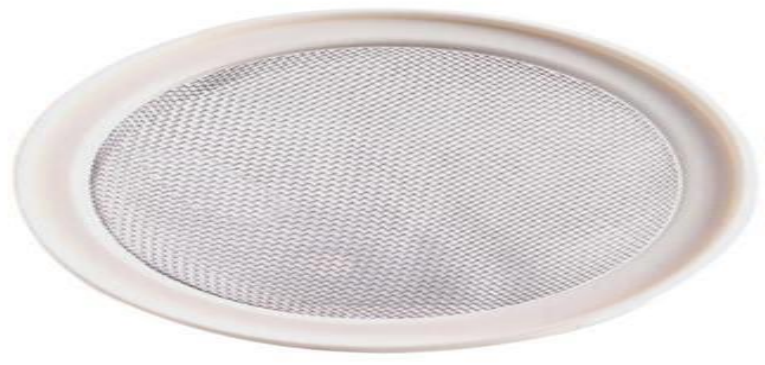

Figure 3.7 Filter

\section{Materials}

The materials used are as follows:

a. $\mathrm{CPO}, \mathrm{CPO}$ is vegetable oil that is produced from palm oil fruit.

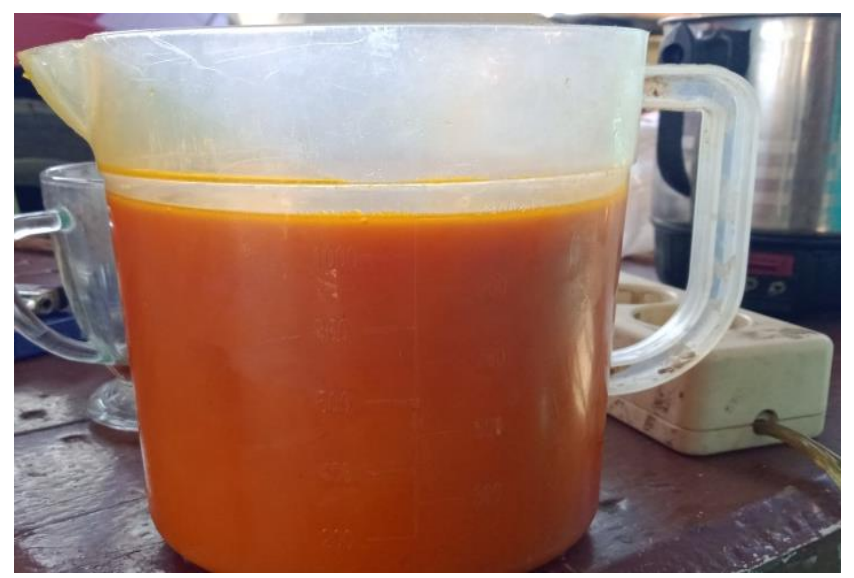

Figure 3.8 CPO

b. Phosphoric acid, Phosphoric Acid is a material that can be used as an addictive to stabilize acidic solutions in the $\mathrm{pH}$ range that you want to set.

Figure 3.5 Funnel 


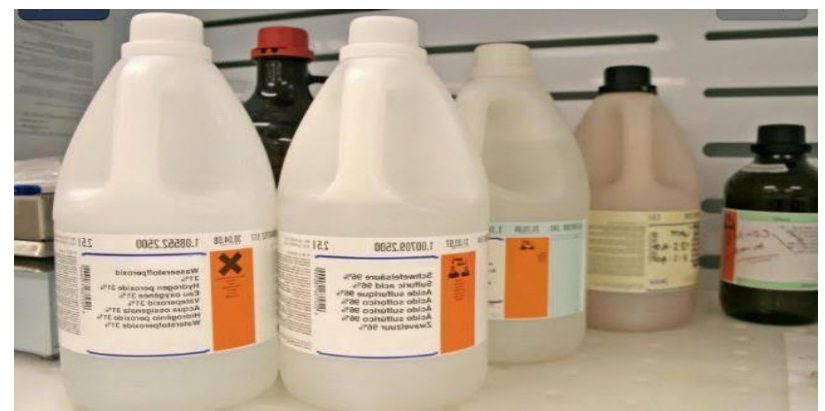

Figure 3.9 Pospic Acid

c. caustic soda, caustic soda is a material that can be used as an addictive to stabilize acidic solutions within the $\mathrm{pH}$ range you want to set.

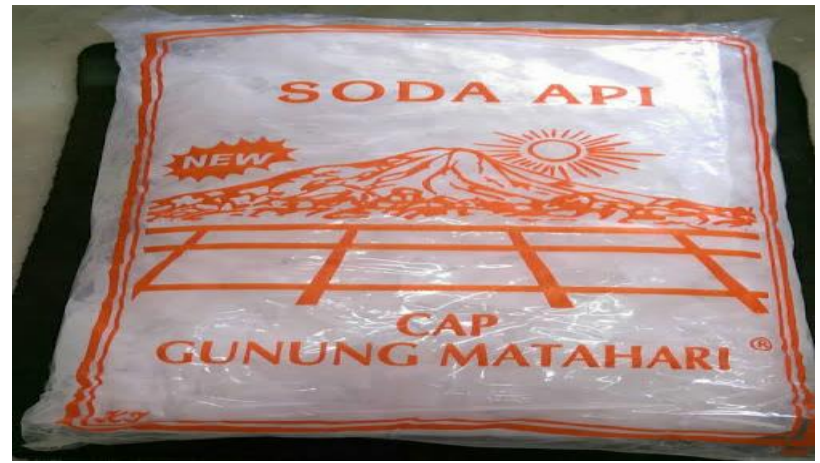

Figure 3.10 caustic soda
The research methodology used is as follows: Studi Literature

1. At this stage, the theories and research concepts that have been developed previously and which are related to the problems faced are presented as a basis for the next stage, literature study is carried out by studying the theories that will be used to achieve the research objectives to be achieved. Literature studies carried out on biomass briquette stoves are obtained from several books, as well as e-books and related journals.

2. Data collection is a systematic and standard procedure for obtaining the required data

\section{Results And Discussion}

\section{A. Biodiesel manufacturing data}

Data for making biodiesel with a mixture of CPO, phosphoric acid and lye with a mixture of $98 \%$ : $1 \%$ : $1 \%, 95 \%$ : $2 \%$ : $3 \%$, and $95 \%: 3 \%: 2 \%$

\section{Research methods}

Table 4.1 Biodiesel production data

\begin{tabular}{|l|l|l|l|l|l|l|l|l|l|}
\hline N0 & $\begin{array}{l}\text { TA1 } \\
\left({ }^{\circ} \mathrm{C}\right)\end{array}$ & $\begin{array}{l}\text { TA2 } \\
\left({ }^{\circ} \mathrm{C}\right)\end{array}$ & $\begin{array}{l}\text { CPO } \\
(\mathrm{gr})\end{array}$ & $\begin{array}{l}\text { phosphoric } \\
\text { acid }(\mathrm{gr})\end{array}$ & $\begin{array}{l}\text { Caustic } \\
\text { soda }(\mathrm{gr})\end{array}$ & $\begin{array}{l}\text { Time } \\
(\mathrm{menit})\end{array}$ & $\begin{array}{l}\text { quantity } \\
(\mathrm{gr})\end{array}$ & $\begin{array}{l}\text { weight } \\
\text { awal } \\
\text { (gr) }\end{array}$ & $\begin{array}{l}\text { final } \\
\text { weight } \\
(\mathrm{gr})\end{array}$ \\
\hline 1 & 30 & 50 & 196 & 2 & 2 & 15 & 200 & 196,02 & 179,84 \\
\hline 2 & 30 & 50 & 190 & 4 & 6 & 13 & 200 & 190.29 & 165,64 \\
\hline 3 & 30 & 50 & 190 & 6 & 4 & 12 & 200 & 190,79 & 156,15 \\
\hline
\end{tabular}

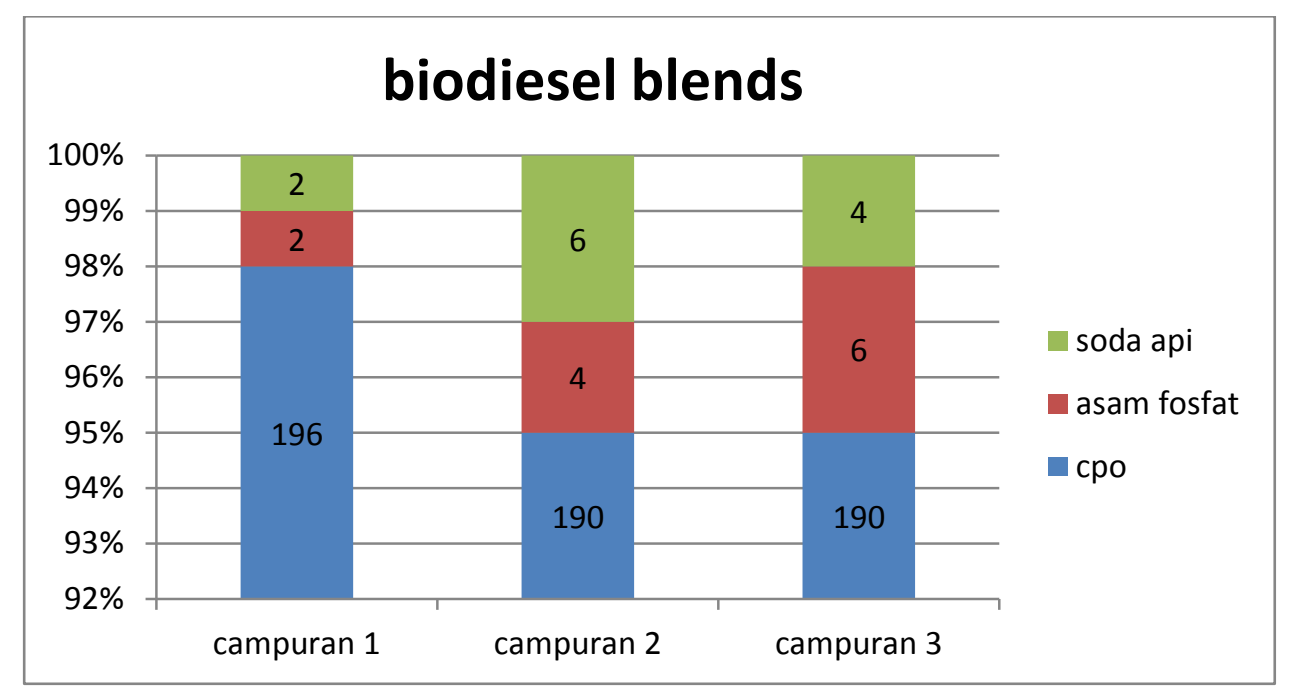

Figure 4.1 Biodiesel Production 


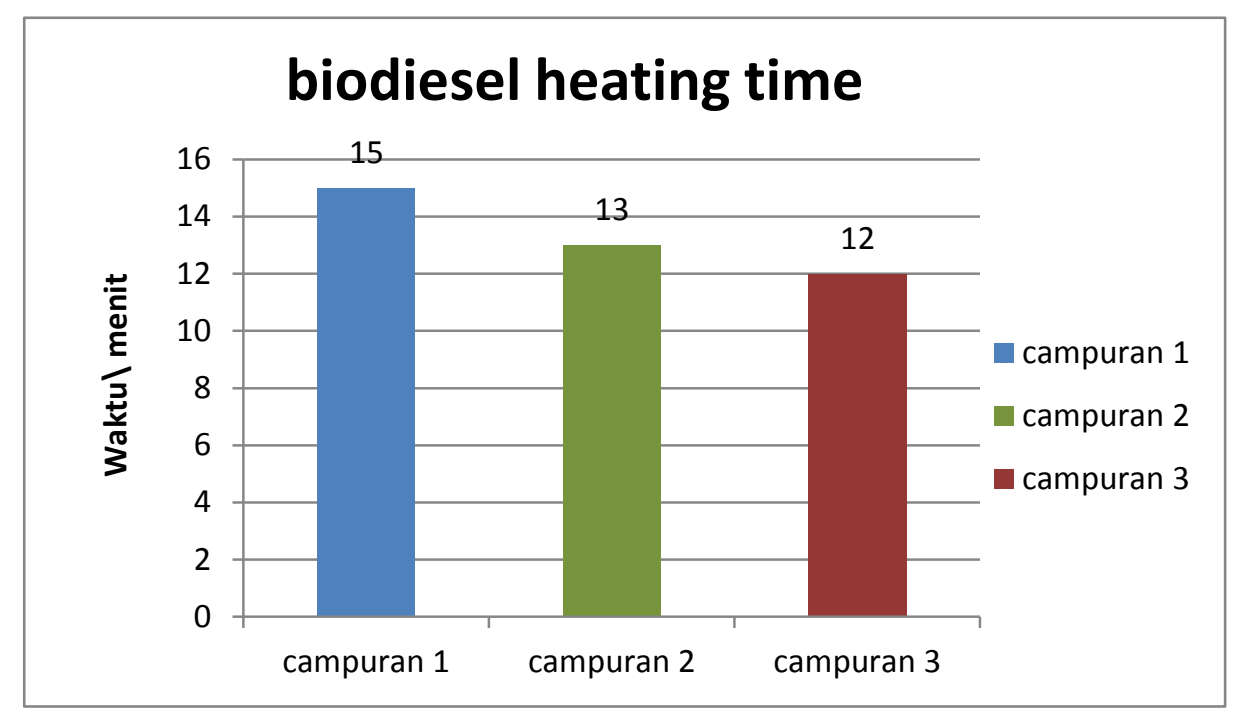

Table 4.2 combustion rate

\begin{tabular}{|l|l|l|l|l|l|l|}
\hline No & $\begin{array}{l}\text { Volume } \\
(\mathrm{ml})\end{array}$ & $\begin{array}{l}\text { weight } \\
(\mathrm{gr})\end{array}$ & $\begin{array}{l}\text { Time } \\
(\mathrm{menit})\end{array}$ & $\begin{array}{l}\text { initial } \\
\text { temperature }\left({ }^{(} \mathrm{C}\right)\end{array}$ & $\begin{array}{l}\text { final temperature } \\
\left({ }^{\circ} \mathrm{C}\right)\end{array}$ & $\begin{array}{l}\text { burning rate } \\
(\mathrm{gr} / \mathrm{menit})\end{array}$ \\
\hline 1 & 10 & 9,12 & 47,50 & 30 & 52 & 0,192 \\
\hline 2 & 10 & 9,46 & 21,48 & 30 & 40 & 0,440 \\
\hline 3 & 10 & 9,41 & 30,42 & 30 & 57 & 0,309 \\
\hline
\end{tabular}

\section{Graph 4.3 Combustion rate}

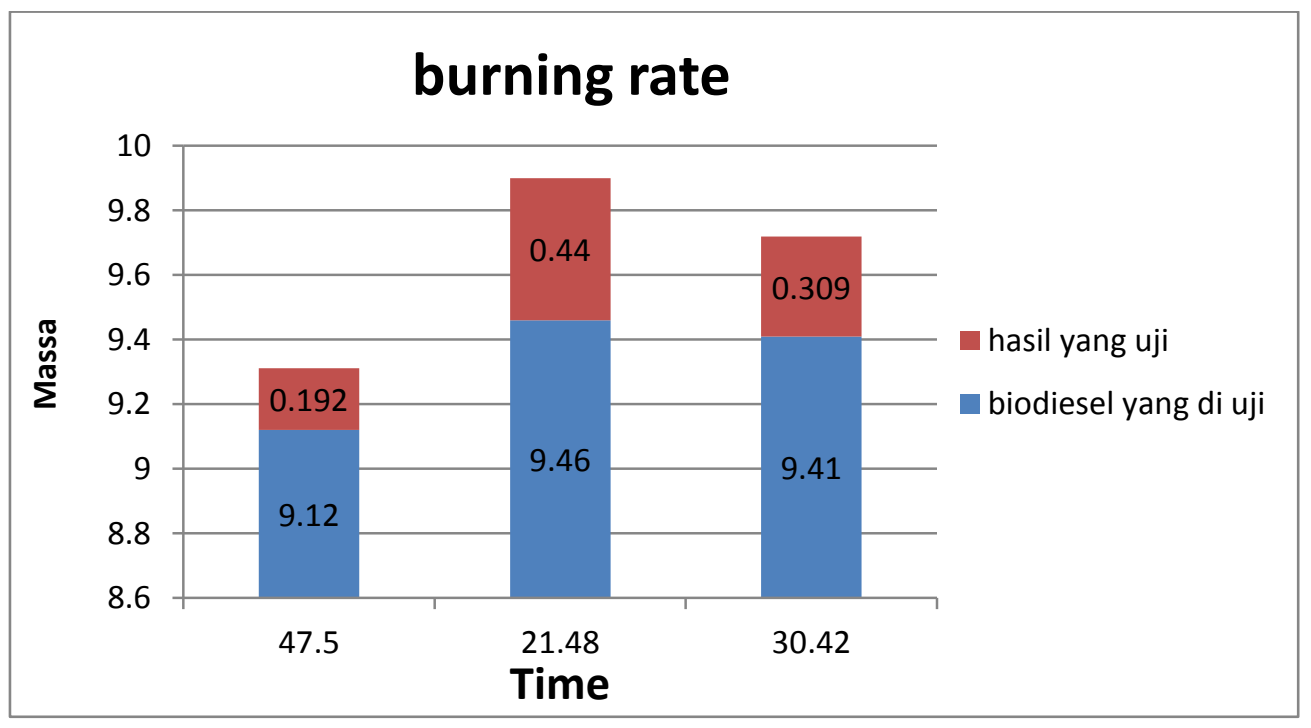

\section{B. Calorific value}

Table 4.3 Calorific value

\begin{tabular}{|l|l|l|l|l|l|l|}
\hline No & Volume (ml) & Weight (gr) & $\begin{array}{l}\text { Time } \\
(\mathrm{menit})\end{array}$ & $\begin{array}{l}\text { Inicial Temperatur } \\
\left({ }^{\circ} \mathrm{C}\right)\end{array}$ & $\begin{array}{l}\text { Final temperatur } \\
\left({ }^{\circ} \mathrm{C}\right)\end{array}$ & $\begin{array}{l}\text { Calorific } \\
\text { Value } \\
(\mathrm{cal} / \mathrm{gr})\end{array}$ \\
\hline 1 & 10 & 9,12 & 47,50 & 30 & 52 & 6213,07 \\
\hline 2 & 10 & 9,46 & 21,48 & 30 & 40 & 8166,80 \\
\hline 3 & 10 & 9,41 & 30,42 & 30 & 57 & 8208,39 \\
\hline
\end{tabular}




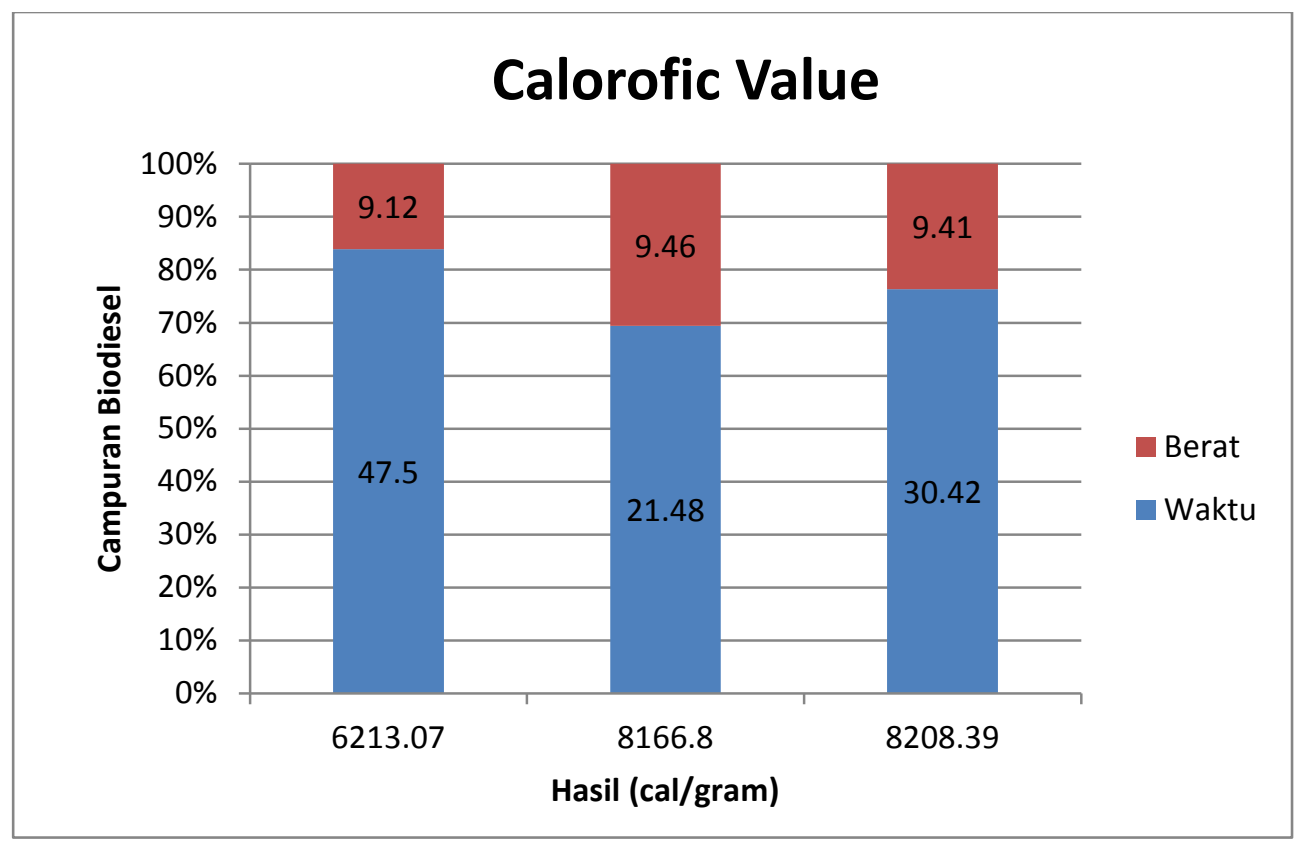

Graph 4.4 Calorific Value

\section{A. Conclusion}

From the calculation results of making biodiesel from CPO, Phosphoric Acid and caustic soda, the following conclusions can be drawn:

1. For a good combustion rate aimed at the third experiment CPO 95\%, 3\% acid phosphate and $2 \%$ fire with a burning rate of $0.309 \mathrm{~g} /$ minute in 30.42 minutes with a final temperature of $57(\mathrm{oC})$

2. The best heating value is shown in the third experiment of $95 \%$ CPO, $3 \%$ phosphoric acid and $2 \%$ fire with a heating value of 8208.39 cal / $\mathrm{g}$ with a final temperature of $57(\mathrm{oC})$.

3. In making biodiesel the chemical composition shows that the more lye, the better and the less phosphoric acid the better

\section{B. Suggestions}

From the research results, it can be suggested to develop further research on the composition of chemical mixtures with varying percentages.

\section{Daftar Pustaka}

[1.] Maliana, N., \& OLEO, U. H. (2016). Pembuatan Biodiesel dari Crude Palm Oil (CPO) Melalui Reaksi Dua Tahap dengan Menggunakan Katalis $\mathrm{H} 2 \mathrm{SO} 4$ dan K2O dari Abu Tandan Kosong Kelapa Sawit (ATKKS). Kendari: Universitas Halu Oleo.

[2.] Andalia, W., \& Pratiwi, I. (2017). Pemilihan katalis menggunakan metode analytical hierarchy process (AHP) pada proses pembuatan biodiesel reaksi transesterifikasi. Journal Industrial Servicess, 3(1a).

[3.] Laila, L. (2017). KAJI EKSPERIMEN ANGKA ASAM DAN VISKOSITAS BIODIESEL BERBAHAN BAKU MINYAK KELAPA SAWIT DARI PT SMART TBK. Jurnal Teknologi Proses dan Inovasi Industri, 2(1).

[4.] Nursuhud, D., \& Pudjanarsa, A. (2008). Mesin Konversi Energi. Yokyakarta: Penerbit Andi.

[5.] Indonesia, C. E. (2011). Buku Panduan Energi yang Terbarukan. Jakarta: Kemendagri-PNPM Mandiri.

[6.] Twidell, J., \& Weir, T. (2015). Renewable energy resources. Routledge.

[7.] Mardani, A., Jusoh, A., Zavadskas, E. K., Cavallaro, F., \& Khalifah, Z. (2015). Sustainable and renewable energy: An overview of the application of multiple criteria decision making techniques and approaches. Sustainability, 7(10), 1394713984.

[8.] Wadud, A. M. A., Zaman, M. T., Rabbee, F., \& Rahman, M. R. (2013). Renewable Energy, an Ideal Solution Of Energy Crisis and Economical Development in Bangladesh. Global Journal of Research In Engineering.

[9.] Mueller, C. J., Cannella, W. J., \& Kalghatgi, G. T. (2014). Fuels for engines and the impact of fuel 
composition on engine performance. Encyclopedia of Automotive Engineering, 1-27.

[10.] Lackner, M., Palotás, Á., \& Winter, F. (2013). Combustion: from basics to applications. John Wiley \& Sons.

[11.] Andalia, W., \& Pratiwi, I. (2017). Pemilihan katalis menggunakan metode analytical hierarchy process (AHP) pada proses pembuatan biodiesel reaksi transesterifikasi. Journal Industrial Servicess, 3(1a).

[12.] Prasetyo, J. (2018). Studi Pemanfaatan Minyak Jelantah Sebagai Bahan Baku Pembuatan Biodiesel. Jurnal Ilmiah Teknik Kimia, 2(2), 45-54.

[13.] Deba, A. A., Tijani, H. I., Galadima, A. I., Mienda, B. S., Deba, F. A., \& Zargoun, L. M. (2015). Waste cooking oil: a resourceful waste for lipase catalysed biodiesel production. International Journal of Scientific and Research Publications, 5.

[14.] Prihanto, A., \& Irawan, T. B. (2018). Pengaruh Temperatur, Konsentrasi Katalis Dan Rasio Molar MetanolMinyak Terhadap Yield Biodisel Dari Minyak Goreng Bekas Melalui Proses Netralisasi-Transesterifikasi. METANA, 13(1), 30-36.

[15.] Mueller, C. J., Cannella, W. J., \& Kalghatgi, G. T. (2014). Fuels for engines and the impact of fuel composition on engine performance. Encyclopedia of Automotive Engineering, 1-27.

[16.] Pramitha, R. I., Haryanto, A., \& Triyono, S. (2017). Pengaruh perbandingan molar dan durasi reaksi terhadap rendemen biodiesel dari minyak kelapa (Coconut Oil). Jurnal Teknik Pertanian Lampung (Journal of Agricultural Engineering), 5(3).

[17.] Rahardja, I. B., Sukarman, S., \& Ramadhan, A. I. (2019). Analisis Kalori Biodiesel Crude Palm Oil (CPO) dengan Katalis Abu Tandan Kosong Kelapa Sawit (ATKKS). Prosiding Semnastek.
[18.] Damarani, Z. N., Sholihah, L. M., Zullaikah, S., \& Rachimoellah, M. (2019). Pra Desain Pabrik Refined Bleached Deodorized (RBD) Olein dari Crude Palm Oil (Oil). Jurnal Teknik ITS, 8(1), F51-F55.

[19.] Nurcahyani, M., Masyhuri, M., \& Hartono, S. (2018). The Export Supply of Indonesian Crude Palm Oil (CPO) to India. Agro Ekonomi, 29(1), 18-31.

[20.] Salas, B. V., Wiener, M. S., \& Martinez, J. R. S. (2017). Phosphoric acid industry: problems and solutions. In Phosphoric Acid Industry-Problems and Solutions. IntechOpen.

[21.] Turmuzi, M., Halimatuddahliana, H., Syaputra, O., \& Fatimah, F. (2017). PENGARUH KONSENTRASI ASAM FOSFAT DALAM PROSES PEMBUATAN KARBON AKTIF SECARA KIMIA DARI BAHAN BAKU KULIT SALAK. ETHOS: Jurnal Penelitian dan Pengabdian kepada Masyarakat, 5(2), 279-283.

[22.] Elkelawy, M., Bastawissi, H. A. E., Esmaeil, K. K., Radwan, A. M., Panchal, H., Sadasivuni, K. K., ... \& Walvekar, R. (2019). Experimental studies on the biodiesel production parameters optimization of sunflower and soybean oil mixture and DI engine combustion, performance, and emission analysis fueled with diesel/biodiesel blends. Fuel, 255, 115791.

[23.] Hezri, A. A., \& Wong, K. Y. (2015). Redefining Sustainable Agriculture for The Developing World. Journal of Oil Palm, Environment and Health (JOPEH), 6.

[24.] Kementerian Perdagangan, R. I. (2013). Laporan akhir analisis dinamika konsumsi pangan masyarakat Indonesia. Jakarta: Pusat Kebijakan Perdagangan dalam Negeri Badan Pengkajian dan Pengembangan Kebijakan Perdagangan Kementerian Perdagangan. 